\title{
Thunderstorms and Lightning in Bangladesh
}

EDITORIAL

\author{
Rahman $\mathrm{SMM}^{1 *}$, Hossain $\mathrm{SM}^{2}$, Jahan $\mathrm{M}^{3}$ \\ ${ }^{1}$ Institute of Public Health, Dhaka, Bangladesh; ${ }^{2}$ Directorate General of Health Services, Dhaka, \\ Bangladesh; ${ }^{3}$ Bangladesh Medical Research Council, Dhaka, Bangladesh
}

A thunderstorm is basically a storm, characterised by lightning and thunder. When the temperature rises, hot moist air rises upwards- known as updrafts. At the same time, the cool air sinks downwards, and this is called downdrafts. Collision between the updrafts and downdrafts creates cumulonimbus clouds and it produces lightning and thunder. Thunderstorms occur almost everywhere on the earth's surface, one of the most dangerous convective weather events. An estimated more than 1600-2400 thunderstorms occur at any moment and 50,000 each day, around the globe. ${ }^{1-4}$

Geographic location of Bangladesh is an indicated zone of natural disaster like storm, drought, flood etc. ${ }^{5}$ Bangladesh is facing a long term climate change (In last 25 years average temperature of Bangladesh increased by $\left.1.5^{\circ} \mathrm{C}\right){ }^{6}$ All thunderstorms produce lightning. Lightning injury is a global public health problem representing the leading cause of weather-related death after tornadoes, flash floods and hurricanes. ${ }^{7,8}$ The injuries cause high mortality and significant long term morbidity.

Worldwide, mortality from lightning is estimated at between 0.2 and 1.7 deaths/1,000,000 population, affecting mainly the young and people who work outdoors. ${ }^{9,10}$ Every year, over 20,000 people are affected by lightning and several thousand succumb to their injuries. ${ }^{11}$ Other report shows some 2,000 people are killed worldwide by lightning each year. ${ }^{12}$

In Bangladesh, only a few studies have been conducted on lightning. These reveal that the number of lightning incidents in the country is quiet high. ${ }^{13,14}$ Another study shows that in Bangladesh, the incidence of lightning fatalities is 0.9 per $1,000,000$ population per year, which is higher than in high-income countries. ${ }^{15} \mathrm{~A}$ total of 1,476 people have died from lightning in Bangladesh during 2010-2016. ${ }^{16}$ Prior to 1981 , the country witnessed lightning strikes on average nine days each May. Since that time, the country has seen strikes an average of 12 days each May. ${ }^{16}$

National summaries of lightning-related deaths and injuries are very difficult to obtain in many developing countries including Bangladesh.

\footnotetext{
*Correspondence: Shah Md. Mahfuzur Rahman, Institute of Public Health, Dhaka, Bangladesh;

e-mail: smahfuzbd@gmail.com
}

In Bangladesh, Dewan et al identified 3,086 fatalities and 2,382 injuries from 1990 to mid-2016, for annual averages of 114 fatalities and 89 injuries over the entire period. Last eight years till 2017, the fatality rate of 2.08 per million population per year and injury rate of 1.7. During 1990 through mid2016, the rural attribution was 93\%, the majority of deaths occur to males, and farming is the major activity. ${ }^{17,18}$ Additional fatalities occurred often inside dwellings, returning home or walking around homesteads, and water-related situations. The trend of many more casualties starting in 2010 has indeed continued. The decadal totals are as follows: ${ }^{18}$

1990-1999: 30 deaths and 22 injuries per year;

2000-2009: 106 deaths and 72 injuries per year, and 2010-2017: 260 deaths and 211 injuries per year. Most lightning fatalities occurred between 0600 LST and 2000 LST when agricultural activities overlap the occurrence of lightning. The largest numbers of casualties were during the pre-monsoon season.

According to the Health Emergency Operation Center \& Control Room, Directorate General of Health Services of Ministry of Health and Family Welfare, in 2018, total deaths and injuries were 120 and 77 respectively due to thunderstorm and lightning. ${ }^{19}$ It was occurred only during the months of March to June, with the highest 68 deaths and 41 injuries in May. In 2019, only till March 2019, the total deaths were 4, and it was in March. ${ }^{19}$

Cardiopulmonary arrest is the most common cause of death in lightning victims. Lightning induces vasomotor spasm from direct sympathetic stimulation resulting in severe loss of pulses in the extremities. This vasoconstriction may be associated with transient paralysis. Damage to the central nervous system accounts for the second most debilitating group of injuries due to lightning. Other organ systems injured by lightning include the eye, ear, gastrointestinal system, skin, and musculoskeletal system. Hundreds more survive strikes but suffer from a variety of lasting symptoms, including memory loss, dizziness, weakness, numbness, and other life-altering ailments. It may be mentioned that lightning is the 
second most common cause of weather-related death in the United States. ${ }^{20}$

Bangladesh is witnessing unusual casualties from lightning strikes well ahead of monsoon, that is in the pre-monsoon season comprises the months of March through May. ${ }^{21}$ It is due to the increased warmer weather and climate change are causing more water evaporation from the land and ocean, increasing cumulonimbus clouds, which is generating fatal lightning strikes. Experts opine that the frequency of lightning has intensified in recent times in Bangladesh due to growing and global warming and environmental imbalance. ${ }^{22}$

Considering the massive death toll due to lightning, in 2016, the Government of Bangladesh has declared it as a natural disaster. ${ }^{16}$ Aimed to reduce the deaths and damage, the Govt. Bangladesh has taken a number of initiatives including plantation of one million palm trees across the countries, development of public awareness on the thunderstorms and lightning through printed and electronic media as well as using other platforms, encourage people to plant palm and other tall tree, installing lightning rods in their houses etc. Furthermore, the warning systems have also been strengthened to make people aware of lighting preparedness. In addition to public awareness and emergency health services for the victims, the Directorate General of Health Services of Ministry of Health and Family Welfare collects information on deaths and injuries due to thunderstorms and lightning across the country regularly.

So, it is evident that the lightning is a public health, social and economic issue. Further strengthening of the current initiatives, epidemiological studies and involving multi-stakeholders and multispecialists to identify the possible and effective measures to reduce the deaths, disabilities and damage and related burden in Bangladesh thus suggested. Furthermore, attention of the global community is urgently sought, considering lightning as a global issue.

\section{References}

1. Saha TR, Quadir DA. Variability and trends of annual and seasonal thunderstorm frequency over Bangladesh. Int. J. Climatol. 2016; 36:4651-4666.

2. Ahrens DC. Meteorology Today. Cengage Learning, Brooks/Cole: Belmont, CA. 2013.

3. Das S. Severe Thunderstorm Observation and Modeling - A Review. Vayu Mandal. 2017; 43: 1-29.

4. Okafor UV: Lightning injuries and acute renal failure: a review. Ren Fail. 2005; 27:129-34.

5. Chakravorti BK. Earthquake forecasting in Bangladesh and its surrounding regions. European Scientific Journal. 2015;11: 238-44.
6. Chakravorti BK, Sarkar P, Rahman A, Rahman A. Thunderstorm and Lightning: the Temperature Effect on Climate Change of Rangpur Region in Bangladesh. Science Journal of Energy Engineering. 2018; 6:31-36.

7. Dutta A. Lightning threat in Bangladesh. The Daily Sun. Dhaka. 21 May 2017.

8. Biswas A, Dalal K, Hossain J, Baset KU, Rahman F, Mashreky SR. F1000Research. 2016; 5:2931.

9. Aslar AK, Soran A, Yildiz Y, et al.: Epidemiology, morbidity, mortality and treatment of lightning injuries in a Turkish burns units. Int J Clin Pract.2001;55:5024.

10. Forster SA, Silva IM, Ramos ML, et al.: Lightning burn-review and case report. Burns. 2013; 39:e8-12.

11. Khatun M, Islam MA, Haque MA. Studies of thunderstorms and lightning on human health, agriculture and fisheries in Mymensingh and Jamalpur district of Bangladesh. Progressive Agriculture 2016; 27:57-63.

12. Impact of a lightning strike.www.nationalgeographic.com/environment/natural-disasters

13. Karim N. Disasters in Bangladesh. Natural Hazards. 1995; 11:247-258.

14. Gomes C, Kithil R, Ahmed M. Developing a lightning awareness program model third world based on American experience, Proc. of the 28th Int. Conference on Lightning Protection (ICLP), Kanasawa, Japan. 2006.

15. Holle RL: Lightning Fatalities in Tropical and Subtropical Regions. Prepr $29^{\text {th }}$ Conf Hurricanes Trop Meteorol. 2010;1-10.

16. Voa News. Bangladesh Declares Lightning Strikes a Disaster as Deaths Surge. 22 June, 2016. https://www.voanews.com/east-asia/bangladeshdeclares-lightning-strikes-disaster-deaths-surge

17. Dewan A, Hossain MF, Rahman MM, Yamane Y, Holle RL. Recent lightning-related fatalities and injuries in Bangladesh, Weather, Climate, and Society. 2017; 9,575-589.

18. Holle RL, Dewan A, Mohammad S, Karim MR, Hossain MF. Lightning Fatalities and Injuries in Bangladesh from1990 through 2017. 25 ${ }^{\text {th }}$ International Lightning Detection Conference $\& 7^{\text {th }}$ International Lightning Meteorology Conference. Ft. Lauderdale, Florida, USA. March 12-15, 2018.

19. Directorate General of Health Services. Ministry of Health and Family Welfare. Dhaka. 2019.

20. Edlich RF, Farinholt HM, Winters KL, Britt LD, Long WB 3rd. Modern concepts of treatment and prevention of lightning injuries. J Long Term Eff Med Implants. 2005; 15:185-96.

21. Karmakar S. Climatology of thunderstorm days over Bangladesh during the pre-monsoon season. Bangladesh J. Sci. \& Tech. 2001; 3:103-122.

22. S Islam, Uddin MN, Alam M, Deb B, Dulal AA. Lightning claims 16 more lives across the country as storms continue. Dhaka Tribune. Dhaka. 1 May 2018. 